\title{
EFFECTS OF CURCUMIN ON INHIBITING THE PROLIFERATION OF PULMONARY ARTERY SMOOTH MUSCLE CELLS AND RELIEVING PULMONARY ARTERIAL HYPERTENSION
}

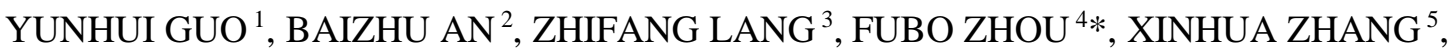 \\ HUAILIANG WANG ${ }^{5}$ \\ ${ }^{l}$ Department of Pharmacology, College of Jiamusi, Heilongjiang University of Chinese Medicine, Jiamusi 154007, China \\ ${ }^{2}$ Department of Anatomy, Mudanjiang Medical University, Mudanjiang 157011, China \\ ${ }^{3}$ Department of Medical Function, Mudanjiang Medical University, Mudanjiang 157011, China \\ ${ }^{4}$ Department of Pharmacology, Mudanjiang Medical University, Mudanjiang 157011, Heilongjiang Province, China \\ ${ }_{5}^{5}$ Department of Clinical Pharmacology, School of Pharmacy, China Medical University, Shenyang, 110122, Liaoning \\ Province, China
}

*corresponding author: wanghuailiang2001@yeah.net

Manuscript received: September 2019

\begin{abstract}
The aim of this study was to explore the protective effect of curcumin on pulmonary arterial hypertension (PAH). A total of 30 male Sprague-Dawley (SD) rats were randomly divided into the blank control group, the monocrotaline (MCT) group, and the MCT + curcumin group. Thirty days after PAH modelling, the pulmonary artery pressures of rats were measured, and the ratio of the right ventricle to the weight of rats was calculated. The rats were sacrificed and lung tissues were collected for the pathological evaluation with haematoxylin and eosin (HE) staining in order to observe the morphological changes and differences of pulmonary arteries. After treatment with different concentrations $(0,5,10$, and $20 \mu \mathrm{mol} / \mathrm{L})$ of curcumin for 24 $\mathrm{h}$, the inhibition of cell proliferation was detected, and the cell cycle variations of pulmonary smooth muscle were observed. Our results showed that curcumin could effectively reduce the pulmonary artery pressure and the ratio of right ventricle/weight in rats, as well as alleviating the thickening of vessel walls of pulmonary arteries and the narrowing of vessels cavities. Consequently, the proliferation of cells was significantly inhibited. In conclusion, curcumin may protect the pulmonary arteries of MCT-induced PHA in rats and inhibit the proliferation of rat pulmonary artery smooth muscle.
\end{abstract}

\section{Rezumat}

Scopul acestui studiu a fost de a explora efectul protector al curcuminei asupra hipertensiunii arteriale pulmonare (PAH). Au fost incluși în studiu 30 de șobolani Sprague-Dawley (SD) randomizați în grupul martor, grupul monocrotalină (MCT) și grupul MCT + curcumină. După treizeci de zile de la inducerea PAH, s-au măsurat presiunile arterei pulmonare și s-a calculat raportul ventricul drept/masă corporală. Șobolanii au fost sacrificați și țesuturile pulmonare au fost colectate pentru evaluare histopatologică. După tratamentul cu diferite concentrații $(0,5,10$ și $20 \mu \mathrm{mol} / \mathrm{L})$ de curcumină timp de 24 de ore, s-a detectat inhibarea proliferării celulare și s-au observat variații ale ciclului celular ale mușchiului neted pulmonar. Conform rezultatelor noastre, curcumina reduce eficient presiunea arterei pulmonare și raportul ventricul drept/masă corporală, atenuează îngroșarea pereților vaselor arterelor pulmonare și îngustarea cavităților vaselor. În concluzie, curcumina poate proteja arterele pulmonare de PHA indusă de MCT la şobolani şi inhibă proliferarea muşchiului neted al arterei pulmonare de şobolan.

Keywords: curcumin, pulmonary arterial hypertension, pulmonary artery smooth muscle cell, monocrotaline

\section{Introduction}

Pulmonary arterial hypertension (PAH) refers to the hemodynamic and pathophysiological state in which pulmonary artery pressure rises above a certain threshold, being a relatively common type of cardiovascular disease $[1,2]$. In accordance with the standards issued by the United States National Institutes of Health (NIH), PAH is identified in accordance with the following criteria: if the mean pulmonary artery pressure of the right heart catheter is $\geq 25 \mathrm{mmHg}$, or the average pulmonary artery pressure is $\geq 30 \mathrm{mmHg}$ [3]. The clinical manifestations of PAH include dyspnoea, fatigue, syncope, haemoptysis, hoarseness, angina and chest pain [4].
Curcumin is a yellow acidic polyphenolic substance extracted from turmeric in traditional Chinese medicine (TCM), with broad pharmacological activities, including anti-inflammatory, anti-oxidation, lipid regulating, anti-viral, anti-infective, anti-tumour, anti-coagulation, anti-liver fibrosis, and anti-atherosclerosis effects [5, 6]. Studies have confirmed that curcumin is an effective therapeutic option for a number of diseases, such as tumours, Alzheimer's disease, heart disease, and rheumatoid arthritis. Curcumin has the advantages of low levels of toxicity and side effects, high safety, and stable efficacy comparative with the standard therapy [7-9]. 
The aetiological factors of PAH are complex, and the primary feature is pulmonary vascular remodelling caused by excessive proliferation of pulmonary vascular smooth muscle. Therefore, the inhibition of pulmonary vascular smooth muscle proliferation is one of the effective methods to control PAH [10-12]. In the current study, we attempted to explore the influence of curcumin on inhibiting the proliferation of pulmonary artery smooth muscle cells and the relief of PHA, aiming to provide a scientific basis for clinical treatment of PAH.

\section{Materials and Methods}

\section{Animals}

A total of 42 male Sprague-Dawley (SD) rats (Kaixue Biotechnology (Shanghai) Co., Ltd., China) (age, 10 weeks; weight, $\sim 200 \mathrm{~g}$ ) were included in the study. The animal experiment was approved by the Ethical Committee of Mudanjiang Medical University, China. All the procedures regarding animal experiments were according to the international laws regarding the use of laboratory animals.

Thirty CD-SD male rats were randomly divided into 3 groups ( $\mathrm{n}=10$ for each group), including blank control group (group A), monocrotaline group (group $\mathrm{B}$ ), and monocrotaline + curcumin group (group C). Rats in group A received by gavage $2 \mathrm{~mL}$ saline solution for 30 days and were allowed free access to food and water. Rats in group B received intraperitoneally monocrotaline solution $(50 \mathrm{mg} / \mathrm{kg} \mathrm{bw})$ (Chengdu Pulis Biology, China) and the next day, stated the administration of $2 \mathrm{~mL}$ saline solution by gavage for 30 consecutive days at a dosage of $2 \mathrm{~mL}$ per day and were allowed free access to food and water. Rats in group $\mathrm{C}$ received intraperitoneally monocrotaline solution $(50 \mathrm{mg} / \mathrm{kg} \mathrm{bw})$ and the next day, started the administration of curcumin (200 mg/kg bw/day) (Ningbo Pharmaceutical Corporation, China) by gavage for 30 consecutive days and were allowed free access to food and water.

The other $12 \mathrm{CD}-\mathrm{SD}$ male rats were randomly divided into 4 groups ( $\mathrm{n}=3$ for each group), including $\mathrm{D}$, $\mathrm{E}, \mathrm{F}$, and $\mathrm{G}$ groups for obtaining the culture of rat smooth muscle cells to be tested for cell viability with methyl thiazolyl tetrazolium (MTT) assay and to be evaluated immunohistochemistry after the treatment with different concentrations of curcumin: group D $(0 \mu \mathrm{mol} / \mathrm{L})$, group E $(5 \mu \mathrm{mol} / \mathrm{L})$, group $\mathrm{F}(10 \mu \mathrm{mol} / \mathrm{L})$ and group $\mathrm{G}(20 \mu \mathrm{mol} / \mathrm{L})$.

Measurement of the proportions of pulmonary artery pressure in rats and the right ventricle to the weight ratio of the rats

Rats in groups A, B, and C were anesthetized by intraperitoneal injection with a mixture of ketamine (100 $\mathrm{mg} / \mathrm{kg}$ bw) (Chengdu SinoStandards Biotechnology, China) and xylazine (10 mg/kg bw) (Baoji GK BioTechnology, China). The right external jugular veins were separated, and the micro-catheters were inserted and fixed. Then, the micro-catheters were slowly pushed into the right atrium and right ventricle. The pulmonary artery pressure of each rat was measured and recorded. The rats were sacrificed through the cervical dislocation method and then both the left and right auricular appendixes of each rat were removed. The right ventricle was cut along the interventricular septum and weighed for the calculation of the ratio of the right ventricle to the weight of the rats.

Haematoxylin-eosin $(H \& E)$ staining for the observation of morphological changes of pulmonary arteries in rats

The lungs of the rats from groups $\mathrm{A}, \mathrm{B}$, and $\mathrm{C}$ were washed with iced saline solution and dried with filter papers. Then, the lungs were placed into the $10 \%$ neutral formalin (Wuhan Boster Biotech Corp., Wuhan, China) for fixation. The lungs were cut open along with the horizontal direction of the left hila of lungs, rinsed with running water, and dehydrated by gradient alcohol. Then the lungs were embedded into paraffin wax and cut into $5 \mu \mathrm{m}$ sections and stained with H\&E. After becoming transparent, the sections were sealed with neutral resins (Shanghai Yantuo Biotech Corp., Shanghai, China) and observed using an optical microscope (Leica, Wetzlar, Germany) for the evaluation of the morphological changes of pulmonary vessels. The percentage of pulmonary artery intima thickness was used as an indicator for the evaluation of pulmonary artery remodelling. One lung tissue section was collected from each rat, and 10 middle pulmonary arteries with a relatively narrow cross-section were selected. Using an image analysis system for morphometric analysis, the outline of the intravascular elastic plate and the outer elastic plate was identified and their diameter was measured, and the average value was calculated. The median thickness of the middle pulmonary artery (WT) and the outer diameter of the blood vessel was obtained. The percentage of medium thickness (WT\%) was calculated according to the following equation:

$\mathrm{WT} \%=2 \times$ media thickness/vascular diameter $\times 100$.

The culture of rat smooth muscle cells

Rats in groups D, E, F, and G were anesthetized by intraperitoneal injection with a mixture of ketamine $(100 \mathrm{mg} / \mathrm{kg} \mathrm{bw})$ and xylazine $(10 \mathrm{mg} / \mathrm{kg}$ bw $)$. Then, in bacteria-free conditions, the thoracic cavity of each rat was opened and exposed, the phosphate-buffered saline (PBS; National Vaccine \& Serum Institute, Beijing, China) was perfused through the pulmonary artery of rats until the buffer was clear or with lighter colour of blood and then $10 \mathrm{~mL}$ of $0.05 \%$ trypsin at $37^{\circ} \mathrm{C}$ was added for $30 \mathrm{~s}$. The pulmonary artery and the left ventricle were closed by clipping for $10 \mathrm{~min}$ and the lung samples were washed with PBS. The tracheal intubation was perfused with $1 \%$ low-melting-point agarose Dulbecco's modified Eagle's medium (DMEM; $40 \mathrm{~mL} / \mathrm{kg}$, Procell Biotech Corp., Shanghai, China) at 
$50^{\circ} \mathrm{C}$. The trunks of lungs, tracheas, and pulmonary blood vessels were cut and placed in the medium in ice for $10 \mathrm{~min}$. Then, the lung lobes of pulmonary artery whose diameters were larger than $200 \mu \mathrm{m}$ were cut off and the remaining tissues were cut into a number of pieces as small as possible, digested by collagenase (Shanghai Yubo Biotech Corp., Shanghai, China) for $50 \mathrm{~min}$ at $37^{\circ} \mathrm{C}$, suspended with $2 \mathrm{~mL}$ of $20 \%$ foetal bovine serum (FBS; Genetimes Technology Inc., Shanghai, China) in DMEM, and maintained at $37^{\circ} \mathrm{C}, 5 \% \mathrm{CO}_{2}$ in a humidified incubator (Shanghai SANTN Instrument Co., Ltd., Shanghai, China). After $24 \mathrm{~h}, 2 \mathrm{~mL}$ of $20 \%$ FBS was added. $48 \mathrm{~h}$ later, the culture dish was gently buffered with PBS, and the solution was changed every 2 days. After 10 days, the cell mass was removed and 4 days later, it was fused into a single layer, digested with $0.02 \%$ trypsin (Shanghai Yaxin Biotechnology Co. Ltd., Shanghai, China) at a ratio of 1:3 for passage, and cultured with $10 \%$ FBS. In accordance with the cell activity, it could be passaged for 3 to 5 generations.

Immunohistochemistry staining for determining the smooth muscle cells of rats

The above pre-treated cells were selected and precooled with paraformaldehyde (4\%, Wuhan Boster Biotech Corp., Wuhan, China) for 5 min for fixation. Then, the cells were permeabilized for 10 min by precooled 10\% dimethyl sulfoxide (DMSO; Sigma-Aldrich, St. Louis, MO, USA), 10\% rabbit serum (Beijing Solarbio Science \& Technology Co., Ltd., Beijing, China) was added, and sealed at $4^{\circ} \mathrm{C}$ for $1 \mathrm{~h}$. The blocking solution was blotted and the diluted solution of the first antibody ( $\alpha$-actin polyclonal antibody, 1:100) (Abace Biology, Beijing, China) was added at $4^{\circ} \mathrm{C}$ for $1 \mathrm{~h}$. Then, the cell samples were three times rinsed with PBS for 3 min each and the solution of the second antibody (rabbit anti-mouse FITC, 1:200) (Shanghai Xiyuan Biotechnology Co. Ltd., Shanghai, China) was added and incubated at dark for $30 \mathrm{~min}$ at $4{ }^{\circ} \mathrm{C}$. The morphology of primary cultured cells was observed using an inverted phase-contrast fluorescence microscope (Leica, Wetzlar, Germany) and a transmission electron microscope.

MTT assay for evaluation of cell proliferation

The MTT assay was applied to assess the inhibition of cell proliferation. The cells were seeded at a density of $1 \times 10^{3}$ cells/well into a 96-well plate. After being attached to the walls, the cells were cultured by serumfree medium for $24 \mathrm{~h}$ and different concentrations of curcumin were added: group D $(0 \mu \mathrm{mol} / \mathrm{L})$, group $\mathrm{E}$ $(5 \mu \mathrm{mol} / \mathrm{L})$, group $\mathrm{F}(10 \mu \mathrm{mol} / \mathrm{L})$, and group $\mathrm{G}(20$ $\mu \mathrm{mol} / \mathrm{L})$. Afterward, the plate was incubated in a humidified incubator at $37^{\circ} \mathrm{C}, 5 \% \mathrm{CO}_{2}$. After $24 \mathrm{~h}$, the supernatant was pipetted and discarded, the MTT solution (Shanghai Yuan Mu Biotechnology Co. Ltd.,
Shanghai, China) was added at $0.5 \mathrm{mg} / \mathrm{mL}$ under slow mixing. The mixture was returned to the incubator for another $3 \mathrm{~h}$ and then $200 \mu \mathrm{L} /$ well DMSO (Qingdao Qingmei Biotechnology Co. Ltd., Qingmei, China) was added and the plate was gently shaken for the complete mixing of the mixture. The automatic enzyme mark instrument (Molecular Devices, San Jose, CA, USA) was applied to measure the absorbance value "A" at a wavelength of $570 \mathrm{~nm}$. The inhibition rate was calculated through the absorbance value, and the equation was as follows: inhibition rate $\eta=$ ("A" value of the control group - "A" value of the experiment group) / "A" value of the control group. Flow cytometry for the detection of cell cycles

The cells were seeded at a density of $1 \times 10^{3}$ cells/ well into a 96-well plate. The cells were cultured for $24 \mathrm{~h}$ after being attached to the walls and different concentrations of curcumin were added $(5,10$, and $20 \mu \mathrm{mol} / \mathrm{L}$ ) for $24 \mathrm{~h}$. Then, the cells were rinsed with PBS, and digested by $0.1 \%$ trypsin to $0.01 \%$ ethylenediaminetetraacetic acid (EDTA, Hunan Huateng Pharmaceutical Co., Ltd., Changsha, China). Next, the cells were centrifuged (Beckman Coulter, Brea, CA, USA) at $100 \mathrm{rpm}$ for $10 \mathrm{~min}$, fixed by $70 \%$ ethanol, and stored overnight at $-2{ }^{\circ} \mathrm{C}$. The next day, the cells were processed by adding $20 \mathrm{mg} / \mathrm{L}$ RNase A and $50 \mathrm{mg} / \mathrm{L}$ propidium iodide (PI; Shanghai Jialun Biotech Co. Ltd., Shanghai, China) for $30 \mathrm{~min}$. The distribution of the cell cycle was analysed by a flow cytometry analyser (EPICS XL/XL-MCL, Beckman Coulter, Brea, CA, USA), 5 times for each group. Statistical analysis

In this study, SPSS 15.0 software (IBM, Armonk, NY, USA) was used for statistical analysis. The normally distributed quantitative data were expressed as mean \pm standard deviation (SD). Intra-group comparisons were performed by independent-samples t-test or rank-sum test. Inter-group comparisons were carried using the Chi-square test.

\section{Results and Discussion}

Effects of curcumin on the rat pulmonary artery pressure The pulmonary artery pressure of groups B and C were significantly increased compared with group A $(\mathrm{p}<0.05)$ (Figure 1A). The pulmonary artery pressure in group $\mathrm{C}$ was significantly decreased compared to the value of group B $(\mathrm{p}<0.05)$.

Effects of curcumin on the right ventricle/weight ratio in rats

The right ventricle/weight ratio in group B was significantly increased compared with that of group A $(\mathrm{p}<0.05)$ (Figure 1B). The right ventricle/weight ratio in group $\mathrm{C}$ was significantly decreased compared to the value of group B $(\mathrm{p}<0.05)$. 


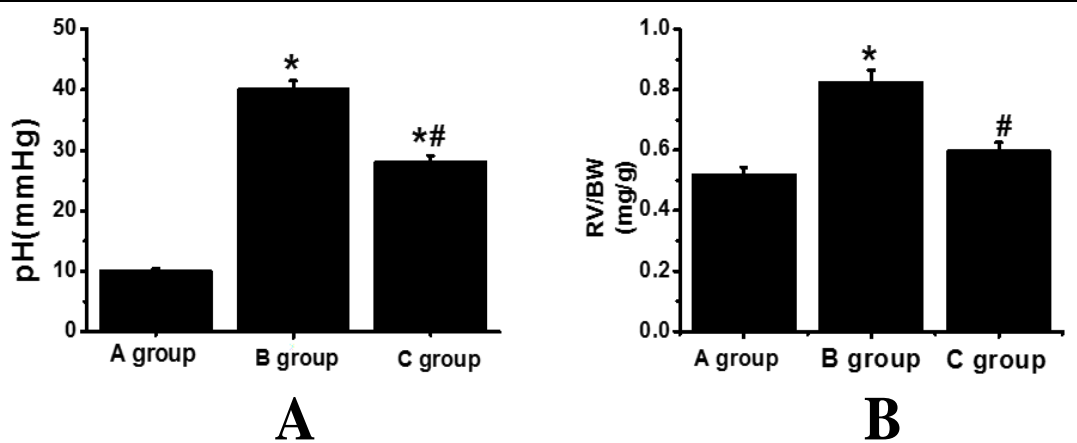

Figure 1.

Pulmonary artery pressure and the right ventricle/weight ratio in rats

(A. The effects of curcumin on pulmonary artery pressure in rats; B. The effects of curcumin on right ventricle/weight ratio in rats)

\section{Changes of vessel walls of pulmonary arteries}

As shown in Figure 2, the endothelial cells of the pulmonary vascular walls in group A were flat, continuous, and evenly distributed, with normal thickness of the vessel walls. In group B, the vessel walls were significantly thickened compared to group A. The pulmonary vascular walls in group $\mathrm{C}$ were slightly thickened as well.

The WT\% evaluation results of rat pulmonary artery were shown in Table I. The WT\% of groups B and $\mathrm{C}$ was significantly increased compared to group A (p < 0.05), while the WT\% of group C was significantly decreased compared to group $\mathrm{B}(\mathrm{p}<0.05)$.

Table I

WT\% of rat pulmonary artery

\begin{tabular}{cc}
\hline Groups & WT\% \\
\hline Group A & $10.34 \pm 1.12$ \\
Group B & $24.15 \pm 2.1^{4 *}$ \\
Group C & $15.98 \pm 1.76^{* \#}$ \\
\hline
\end{tabular}

${ }^{*} \mathrm{p}<0.05$ compared with group $\mathrm{A} ;{ }^{*} \mathrm{p}<0.05$ compared with group B

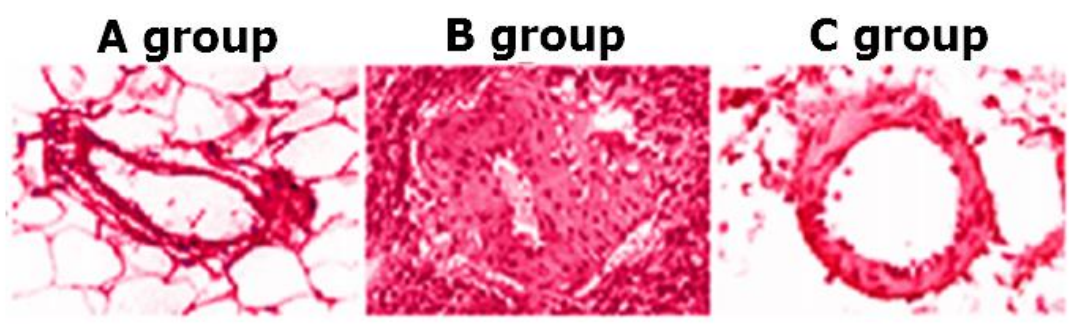

Figure 2.

Optical microscopic results of HE staining

A

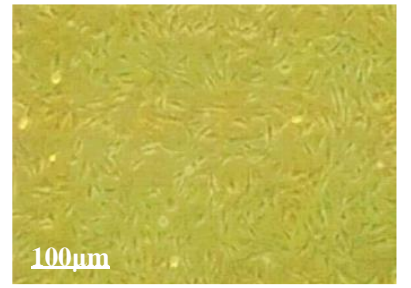

B

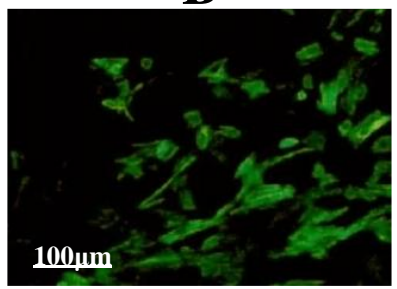

C

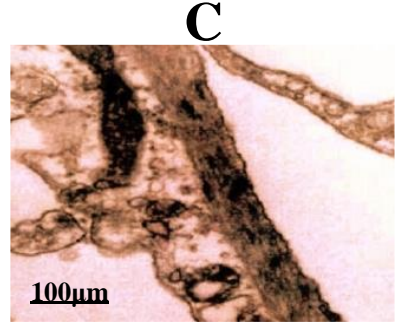

Figure 3.

Morphology of rat pulmonary smooth muscle cells observed under microscopes: A. indicated the results of an inverted trinocular phase contrast fluorescence microscopy; B illustrated the results of immunofluorescence staining; C displayed the results under a transmission electron microscope $(\times 40000)$

Determinations of pulmonary smooth muscle cells Under an inverted trinocular phase contrast fluorescence microscope, the primary lung smooth cells showed the typical growing characteristics of pulmonary vascular smooth muscle cells, which was the "peak-to-valley" growth, as illustrated in Figure 3A. The $\alpha$-actin immunofluorescence staining was positive with green fluorescence, as shown in Figure 3B and the dense bodies and dense spots were observed in the basement membrane and cytoplasm under the transmission electron microscope, as displayed in Figure 3C.

MTT assay

In the MTT assay, after the curcumin treatment, the inhibition rates of rat pulmonary smooth muscle cells 
in groups $\mathrm{E}, \mathrm{F}$, and $\mathrm{G}$ were increased compared with those from group $\mathrm{D}(0 \mu \mathrm{mol} / \mathrm{L}$ of curcumin $)(p<0.05)$. The inhibitory effect of curcumin on the pulmonary smooth muscle cell proliferation was dose-dependent and significant when compared with the control group $(0 \mu \mathrm{mol} / \mathrm{L}$ curcumin $)(\mathrm{p}<0.05)$ (Figure 4$)$.

Flow cytometry

Compared with the blank control group ( $0 \mu \mathrm{mol} / \mathrm{L}$ of curcumin) the cells in $\mathrm{S}$ phase (synthesis, DNA synthesis stage) in the curcumin groups were significantly reduced ( $p<0.05$ ), while the cells in G0/G1 phase (first gap, the early stage of DNA synthesis) increased in a dose-dependent manner without reaching the statistical significance. As the concentration of curcumin increased, the percentage of cells in G0/G1 phase increased, and the cell cycle remained in the G0/G1 phase. The inhibitory effects of curcumin at a concentration of $20 \mu \mathrm{mol} / \mathrm{L}$ were the strongest (Table II).

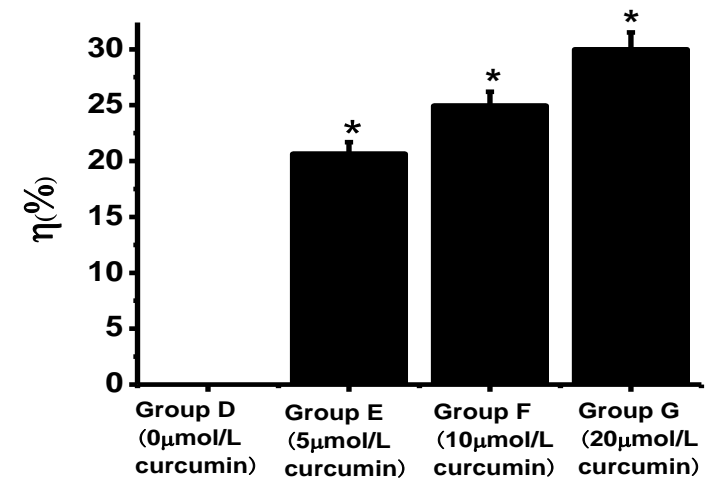

Figure 4.

Effects of different concentrations of curcumin on inhibition rates of rat pulmonary smooth muscle cells

Table II

Effects of different concentrations of curcumin on the cell cycle variations of rat pulmonary smooth muscle cells

\begin{tabular}{ccc}
\cline { 2 - 3 } Curcumin $(\mu \mathrm{mol} / \mathrm{L})$ & S cycle $(\%)$ & G0/G1 cycle $(\%)$ \\
\hline 0 & $40.9065 \pm 2.22423$ & $45.0013 \pm 4.99042$ \\
5 & $35.6863 \pm 2.41054^{*}$ & $55.3958 \pm 5.01320^{*}$ \\
10 & $30.1702 \pm 3.00536^{*}$ & $58.7328 \pm 5.11247^{*}$ \\
20 & $23.7994 \pm 3.11259^{*}$ & $63.0100 \pm 5.20381^{*}$ \\
\hline
\end{tabular}

$(\mathrm{x} \pm \mathrm{s})$

$* \mathrm{p}<0.05$ compared with the blank control group $(0 \mu \mathrm{mol} / \mathrm{L}$ of curcumin $)$

Monocrotaline (MCT) is a pyrrolizidine alkaloid phytotoxin extracted from leguminous plants that was shown to cause irreversible damages to pulmonary vascular endothelial cells. The endothelial cells are vital in pulmonary vascular remodelling [13, 14]. Based on these properties, monocrotaline is frequently used to induce PAH in various animal models. The MCT injection to the rats determines delayed pulmonary vascular injuries accompanied by a series of changes, including platelet thrombosis and smooth muscle hyperplasia that lead to an increased pulmonary artery pressure $[15,16]$. In the current study, we used a murine model of PAH by injecting MCT to the rats. It was observed a significant increase in the pulmonary artery pressure in the monocrotaline treated rats compared to the blank control group suggesting that the model was successful.

The pulmonary artery pressure and the right ventricle/ weight ratio in the curcumin group were significantly lower compared to the MCT group. As it could be seen from the pathological evaluation, the vascular lesions in the curcumin group were alleviated, the tunica media was thickened, and the degree of stenosis of the vascular cavity was reduced compared with the MCT group suggesting the protective effects of curcumin in MCTinduced PHA in rats. These results are in line with other studies that showed the beneficial effect of curcumin in improving the degree of PHA and reduce vascular lesions $[17,18]$. The main factor in PHA pathophysiology was pulmonary vascular remodelling caused by smooth muscle cell proliferation. Previously, it has been reported that curcumin could effectively inhibit the proliferation of pulmonary artery smooth muscle cells [19], this being one of the mechanism through which curcumin could protect against PAH. The proliferation of pulmonary smooth muscle cells is one of the most important causes of pulmonary vascular remodelling, leading to increased pulmonary artery resistance and PHA [20]. In this study, we analyse the effect of curcumin on rat pulmonary smooth muscle cells. It was found that curcumin had noticeable inhibitory effects on cell proliferation stimulated by $10 \%$ FBS, and this effect is dosedependent. Flow cytometry analysis showed that the proportion of $S$ phase of curcumin-treated cells decreased, while the percentage of G0/G1 phase increased. In the cell division cycle, the G0/G1 phase is the early stage of DNA synthesis, a preparation for the $\mathrm{S}$ phase, as well as a critical stage for the cell cycles. Different concentrations of curcumin could interrupt the proliferation of cell cycles and block rat pulmonary smooth muscle cells in G0/G1 phase. The number of cells in the $\mathrm{S}$ cycle could be thereby reduced, and cell proliferation might be inhibited.

\section{Conclusions}

In conclusion, curcumin may inhibit the proliferation of pulmonary artery smooth muscle cells by blocking cell cycle progression, thereby reducing pulmonary artery pressure. This study supports further studies 
aimed to investigate the clinical efficacy of curcumin administration for prevention $\mathrm{PAH}$.

\section{Acknowledgement}

This work was supported by National Natural Science Foundation of China (Grant no. 30973533), The Scientific research projects of basic scientific research in colleges and universities operating expenses of Heilongjiang Province in 2018, China (Grant No. 2018-KYYWFMY-0014).

\section{Conflict of interest}

The authors declare no conflict of interest.

\section{References}

1. Cui X, Song H, Su J, Curcumin attenuates hypoxicischemic brain injury in neonatal rats through induction of nuclear factor erythroid-2-related factor 2 and heme oxygenase-1. Exp Ther Med., 2017; 14(2): 1512-1518.

2. Li S, Zhou F, Dong J, Dong Q, Luan H, Li L, Hao Y, Therapeutic effects of aloperine on the pulmonary arterial hypertension. Farmacia, 2019; 67(4): 691-701.

3. Abdollahi E, Momtazi AA, Johnston TP, Sahebkar A, Therapeutic effects of curcumin in inflammatory and immune-mediated diseases: A nature-made jack-ofall-trades?. J Cell Physiol., 2018; 233(2): 830-848.

4. Mahran RI, Hagras MM, Sun D, Brenner DE, Bringing curcumin to the clinic in cancer prevention: a review of strategies to enhance bioavailability and efficacy. AAPS J., 2017; 19(1): 54-81.

5. Blanco-Garcia E, Otero-Espinar FJ, Blanco-Mendez J, Leiro-Vidal JM, Luzardo-Alvarez A, Development and characterization of anti-inflammatory activity of curcumin-loaded biodegradable microspheres with potential use in intestinal inflammatory disorders. Int J Pharm., 2017; 518(1-2): 86-104.

6. Oyemitan IA, Elusiyan CA, Onifade AO, Akanmu MA, Oyedeji AO, McDonald AG, Neuropharmacological profile and chemical analysis of fresh rhizome essential oil of Curcuma longa (turmeric) cultivated in Southwest Nigeria. Toxicol Rep., 2017; 4: 391-398.

7. Li HY, Yang M, Li Z, Meng Z, Curcumin inhibits angiotensin II-induced inflammation and proliferation of rat vascular smooth muscle cells by elevating PPAR-gamma activity and reducing oxidative stress. Int J Mol Med., 2017; 39(5): 1307-1316.

8. Givertz MM, Stevenson LW, Costanzo MR, Bourge RC, Bauman JG, Ginn G, Abraham WT, Pulmonary artery pressure-guided management of patients with heart failure and reduced ejection fraction. $J A m$ Coll Cardiol., 2017; 70(15): 1875-1886.

9. Biering-Sorensen T, Santos M, Rivero J, McCullough SD, West E, Opotowsky AR, Waxman AB, Systrom DM, Shah AM, Left ventricular deformation at rest predicts exercise-induced elevation in pulmonary artery wedge pressure in patients with unexplained dyspnoea. Eur J Heart Fail., 2017; 19(1): 101-110.

10. Imamura T, Chung B, Nguyen A, Rodgers D, Sayer G, Adatya S, Sarswat N, Kim G, Raikhelkar J, Ota T, Song T, Juricek C, Kagan V, Jeevanandam V, Decoupling between diastolic pulmonary artery pressure and pulmonary capillary wedge pressure as a prognostic factor after continuous flow ventricular assist device implantation. Circ Heart Fail., 2017; 10(9): 1-19.

11. Arian A, Moghadam SG, Kazemi T, Hajihosseini M, The effects of statins on pulmonary artery pressure in patients with chronic obstructive pulmonary disease: a randomized controlled trial. J Res Pharm Pract., 2017; 6(1): 27-30.

12. Gohar S, Taimeh ZA, Morgan JA, Frazier OH, F AA, Civitello AB, Nair AP, Use of remote pulmonary artery pressure monitoring (CardioMEMS System) in total artificial heart to assess pulmonary hemodynamics for heart transplantation. ASAIO J., 2018; 64(4): e75-e77.

13. Fizeșan I, Cambier S, Moschini E, Chary A, Pop A, Kiss B, Serchi T, Gutleb AC, Loghin F, In Vitro Cellular Models, A Resourceful Tool In Respiratory Toxicology. Farmacia, 2018; 66(4): 573-580.

14. Blissenbach B, Nakas CT, Kronke M, Geiser T, Merz TM, Pichler Hefti J, Hypoxia-induced changes in plasma micro-RNAs correlate with pulmonary artery pressure at high altitude. Am J Physiol Lung Cell Mol Physiol., 2018; 314(1): L157-L164.

15. Angermann CE, Assmus B, Anker SD, Brachmann J, Ertl G, Kohler F, Rosenkranz S, Tschope C, Adamson PB, Bohm M, Safety and feasibility of pulmonary artery pressure-guided heart failure therapy: rationale and design of the prospective CardioMEMS Monitoring Study for Heart Failure (MEMS-HF). Clin Res Cardiol., 2018; 107(11): 991-1002.

16. Saragai Y, Takaki A, Umeda Y, Matsusaki T, Yasunaka T, Oyama A, Kaku R, Nakamura K, Yoshida R, Nobuoka D, Kuise T, Takagi K, Adachi T, Wada N, Takeuchi Y, Koike K, Ikeda F, Onishi H, Shiraha H, Nakamura S, Morimatsu H, Ito H, Fujiwara T, Yagi T, Okada H, A subclinical high tricuspid regurgitation pressure gradient independent of the mean pulmonary artery pressure is a risk factor for the survival after living donor liver transplantation. BMC Gastroenterol., 2018; 18(1): 1-10.

17. Li JL, Fan YY, Ye GH, Dong MW, Lin KZ, Li F, Yu LS, Study on the mechanism of how curcumin improves pulmonary vascular remodeling associated with chronic pulmonary arterial hypertension]. Zhongguo Ying Yong Sheng Li Xue Za Zhi, 2014; 30(5):451-455.

18. Lin Q, Wang LX, Chen SX, Zhou XF, Huang XY, Fan $\mathrm{XF}$, Effect of curcumin on pulmonary hypertension and wall collagen of pulmonary arterioles of chronic hypoxic hypercapnic rats. Zhongguo Ying Yong Sheng Li Xue Za Zhi, 2006; 22(3): 257-261.

19. Asari Y, Yamasaki Y, Tsuchida K, Suzuki K, Akashi YJ, Okazaki T, Ozaki S, Yamada H, Kawahata K, Hemodynamic heterogeneity of connective tissue disease patients with borderline mean pulmonary artery pressure and its distinctive characters from those with normal pulmonary artery pressure: a retrospective study. Clin Rheumatol., 2018; 37(12): 3373-3380.

20. Jiang L, Wei XB, He PC, Feng D, Liu YH, Liu J, Chen JY, Yu DQ, Tan N, Value of pulmonary artery pressure in predicting in-hospital and one-year mortality after valve replacement surgery in middle-aged and aged patients with rheumatic mitral disease: an observational study. BMJ open, 2017; 7(5): 1-6. 